\title{
The Aluminium Demand Risk of Terawatt Photovoltaics for Net Zero Emissions by 2050
}

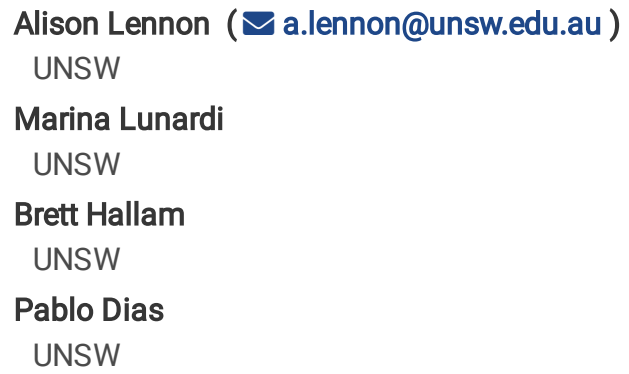

Article

Keywords: photovoltaics, net zero emissions, global warming, aluminium demand

Posted Date: September 7th, 2021

DOI: https://doi.org/10.21203/rs.3.rs-846247/v1

License: (c) (i) This work is licensed under a Creative Commons Attribution 4.0 International License. Read Full License

Version of Record: A version of this preprint was published at Nature Sustainability on January 20th, 2022. See the published version at https://doi.org/10.1038/s41893-021-00838-9. 


\section{Abstract}

The broad electrification scenario of recent photovoltaics roadmaps predicts that by 2050 we will need more than 60 TW of photovoltaics installed and be producing up to 4.5 TW of additional capacity each year if we are to rapidly reduce emissions to 'net-zero' and limit global warming to $<2^{\circ} \mathrm{C}$. Given that after 2020, just over $700 \mathrm{GWp}$ was installed, this represents an enormous manufacturing task which will create a demand for a number of metals. We show here that growth to $60 \mathrm{TW}$ of photovoltaics could require up to $480 \mathrm{Mt}$ of aluminium by 2050 . A key concern for this aluminium demand is its large global warming potential. We predict the cumulative emissions arising from emission reduction scenarios in China and show that rapid decarbonisation of the electricity grid within 10 years will be required if they are to be kept below 1000 Mt CO2e by 2050.

\section{Main}

If global warming is to be limited to less than $2^{\circ} \mathrm{C}$, emissions need to be drastically curtailed to close to net zero before $2050^{1}$. Various technology mitigation scenarios have been proposed to address this challenge ${ }^{2-7}$. However, these scenarios differ significantly in the extent that different clean energy technologies contribute to the required emissions reduction, and particularly, in terms of the anticipated role of solar photovoltaics $(\mathrm{PV})^{2,4-6}$. Historically, technology roadmaps have significantly under-estimated the installed PV capacity 8,9 , and energy agencies are continually revising their technology scenarios to take into account the driving effect that rapidly reducing PV module $\operatorname{costs}^{4}$ are having on installed PV capacities worldwide. The International Energy Agency (IEA) recently markedly increased its renewable energy projections, with solar PV predicted to now provide $32 \%$ of the world's total electricity demand by 2050 . They estimate that this will require an installed PV capacity of $~ 14$ TWp and annual installations of $630 \mathrm{GW}$ each year by $2050^{3}$. However, although this target represents a large increase in the predicted contribution of solar PV over their previous reports, it still falls short of the projections of the International Technology Roadmap for PV (ITRPV)'s broad electrification scenario which forecasts that the total capacity of installed PV needs to be at least $60 \mathrm{TWp}$ by 2050 with annual installations of $4.5 \mathrm{TWp}$ being required close to that date ${ }^{4}$. This ambitious target is projected because of the extremely low cost of PV generated electricity compared to all other energy sources. In the last 10 years, the spot price of PV modules has decreased by about $90 \%$ to be less than US $\$ 0.20 / \mathrm{W}^{10}$ and the median levelised cost of electricity from solar PV is < US\$50/MWh; less than costs of electricity from both coal and gas in many countries including the US, China, India and Australia ${ }^{11}$.

There is now a consensus that we will need tens of TW of installed PV capacity and annual production will need to approach TW levels by $2050^{9}$ or even sooner in order to decarbonise electricity grids ${ }^{10}$. Given that, at the end of 2020, there was just over $700 \mathrm{GWp}$ installed ${ }^{12}$ with $130 \mathrm{GWp}$ having been added in 2020 alone ${ }^{4}$, this represents an enormous manufacturing scaling up task requiring significant mineral resources. Consequently, the material sustainability assumptions made in the various emission reduction technology scenarios need to be carefully evaluated ${ }^{13,14}$. To date, the material sustainability of TW PV has typically focussed on the elements required for the anticipated mainstream technology cells, such as silver and indium ${ }^{10,15}$. However, the demand risk of other metals that will be required in large volumes for PV, such as aluminium, also needs to be evaluated. Due to its high conductivity, low weight and excellent corrosion resistance, aluminium is used in the mountings, frames, inverters and in the cells of terrestrial flat panel PV modules ${ }^{16}$. It is also heavily used by many other clean energy technologies ${ }^{13}$. However, despite its desirable attributes, its primary production comes at a high cost in terms of energy and associated greenhouse gas emissions through both direct and indirect emissions.

In its "Minerals for Climate Action" report ${ }^{13}$, the World Bank identified aluminium as being a mineral of high demand risk because: (i) it is required by a number of clean energy technologies; (ii) its predicted usage will require extensive increases in production by 2050; and (iii) the required mining and primary production of aluminium has a large global warming potential (GWP) ${ }^{13}$. They also showed that solar PV dominated this demand, contributing $87 \%$ to the total additional demand. However, the World Bank analysis assumed the IEA's earlier $2^{\circ} \mathrm{C}$ technology mitigation scenario which predicted only 4 TWp installed PV capacity by 2050 and for $50 \%$ of that share to be crystalline silicon ${ }^{7}$. To place this in perspective, 95\% of installed PV in 2020 was crystalline silicon (up from 80\% in 2010) and 4 TWp (in 2050) is only a sixfold increase from the installed capacity at the end of 2020. The question that we seek to address is, if we are going to have more than 60 TWp of PV installed by 2050 and be installing an additional 4-5 TWp each year, what is the real demand risk for aluminium?

Aluminium is one of the most recycled and most recyclable materials on the market today ${ }^{17}$. It is attractive to recycle because its secondary production requires only $5 \%$ of the energy required for primary production ${ }^{18}$ and generates just $3-5 \%$ of the emissions from primary production ${ }^{18-20}$. Nearly $75 \%$ of all the aluminium produced is still in use today ${ }^{21-23}$ and end-of-life (EOL) recycling rates are estimated at 34$63 \% 19,21-23$. However, a key constraint for secondary production is the availability of aluminium scrap. Primary aluminium production involves two processes (see Fig. 1): (i) refining of bauxite ore into alumina (via the Bayer process ${ }^{24}$ ); and (ii) aluminium smelting via electrolysis of alumina (via the Hall-Héroult electrolysis process ${ }^{25}$ ). The energy requirements of the entire aluminium primary production 
process have been estimated to be $62.6 \mathrm{GJ}$ per tonne of sawn aluminium ingot, which is significantly higher than for steel or copper (see Table S1). The emissions intensity of primary production is dominated by the indirect emissions from the required electricity. The world average emission intensity for aluminium primary production in 2018 was $\sim 17 \mathrm{t} \mathrm{CO}_{2} \mathrm{e} / \mathrm{t}$ aluminium ${ }^{17}$ and the International Aluminium Institute (IAI) predicts that this value can be reduced to $5-6 \mathrm{t} \mathrm{CO}_{2} \mathrm{e} / \mathrm{t}$ aluminium with decarbonised electricity ${ }^{17}$.

We use the most recent PV projections to more accurately evaluate the aluminium demand required to support the broad electrification scenario of the most recent ITRPV and its associated GWP. It is assumed that crystalline silicon PV will remain the dominant PV technology 4 rather than reduce to $50 \%$ market share as assumed by the World Bank analysis. Emissions were calculated assuming that both aluminium production and PV manufacturing occur predominantly in China, and that aluminium is obtained through both primary and secondary (recycled) production pathways.

In our GWP analysis, we use current estimates of primary production emissions intensity in China and consider different emissions reduction scenarios. Our modelling assumes that the available secondary aluminium in China is as forecast by Li et al.20, and we evaluate the sensitivity of our estimated GWP arising from the required aluminium demand to the fraction of that secondary pool which is available for the PV capacity additions. We conclude by discussing paths by which this imminent aluminium demand risk can be addressed in terms of possible PV technology decisions and technology advancements which will be required to realise reductions in the aluminium emissions intensity.

\section{Results}

\section{Aluminium Demand}

Figure 2 shows the annual and cumulative aluminium demand for the solar cells, module frames, mountings and inverters required for the PV capacity additions predicted by the 2021 ITRPV's broad electrification scenario ${ }^{4}$ leading to a total of 60 TW of PV in 2050 . The assumptions used are detailed in Table 1 and the Methods. In the shown base case, power derating due to module operation in the field was assumed to be negligible with respect to the new capacity required and the share of rooftop modules was projected to decrease from $50 \%$ in 2020 to $40 \%$ by $2050^{6}$. Our analysis predicts a much larger cumulative aluminium demand of $486 \mathrm{Mt}$ (for 60 TWp by 2050) than the $103 \mathrm{Mt}$ predicted by the World Bank report in $2020^{13}$ (for 4 TWp by 2050). The increase was expected due to the larger installed PV capacity associated with the ITRPV's broad electrification scenario. However, the 4.7 fold increase is much smaller than the factor of 15 increase in installed capacity due to our model assuming anticipated energy conversion and technology efficiency increases over the 2020 to 2050 timeframe. 
Table 1

Parameters used in the aluminium demand modelling

Parameter Value

Projected PV Capacity (GW)

i. Total installed PV capacity per year until 2050 (GW)

Annually as predicted for the broad electrification scenario in ${ }^{4}$ and reaching 60 TW in 2050

ii. Annual added capacity PV in 2050 (GW)

4.5 TW in $2050^{4}$

iii. Market share of crystalline silicon (including silicon tandem technology)

$100 \% 4,46$

iv. Fraction of rooftop PV (\%)

$50 \%$ in 2019 and decreasing to $40 \%$ in $2050^{6}$ (base)

v. PV power de-rating in the field (\%)

$0.5 \%$ average annual degradation ${ }^{26}$

Crystalline Silicon Module Specifications

i. Utility scale module power (W)

$450 \mathrm{~W}(20.5 \%)$ in $2020^{4}$ increasing to $615 \mathrm{~W}$ (24.6\% in 2050 for 144 half-cell M6 modules (base).

ii. Utility-scale module area $\left(\mathrm{m}^{2}\right)$

Increasing from $2.2 \mathrm{~m}^{2}$ in $2020^{4}$ to $2.5 \mathrm{~m}^{2}$ in 2050

iii. Rooftop module power (W)

$375 \mathrm{~W}(20.8 \%)$ in $2020^{4}$ increasing to $510 \mathrm{~W}(25.5 \%)$ in 2050$)$ for 120 half-cell M6 modules.

iv. Rooftop module area $\left(\mathrm{m}^{2}\right)$

$1.8 \mathrm{~m}^{2}$ in $2020^{4}$ increasing to $2.0 \mathrm{~m}^{2}$ in 2050

Aluminium Usage (cells, modules, system)

i. Cells (e.g., PERC) ${ }^{4}$

800 mg/M6 monofacial cell (2021) to 700 mg/M6 (2030)

200 mg/M6 bifacial cell (2021-2030)

Bifacial \% increasing from 28\% (2021) to 78\% (2030)

Only PERC needs Al; Fraction PERC 85\% (2021) decreasing to 50\% (2030)

ii. PV module frames $(\mathrm{t} / \mathrm{GW})$

$1.2 \mathrm{~kg} / \mathrm{m}^{2}$ based on $0.5 \mathrm{~kg} / \mathrm{m}$ calculated assuming a $600 \mathrm{~W}$ Trina Vertex module (TSM-DEG20C.20 of area $2.83 \mathrm{~m}^{2}$ ).

iii. Rate of frameless modules (\%)

$7 \%$ in $2020^{4}$ increasing to $50 \%$ by 2050

iv. PV rooftop mountings (t/GW)

$2.84 \mathrm{~kg} / \mathrm{m}^{2} 43$ reducing by $0.5 \%$ per year to $\sim 2.4 \mathrm{~kg} / \mathrm{m}^{2}$ in 2050

v. PV utility-scale mountings (t/GW)

0; assume predominantly steel

vi. Inverters

$0.48 \mathrm{~kg} / \mathrm{kW}^{47}$; Assuming no replacement required between 2020 and 2050

If PV modules degrade in the field by $\sim 0.5 \%$ per year $^{26}$, the aluminium demand will increase by $4.7 \%$ to $515 \mathrm{Mt}$ by 2050 to accommodate the production of replacement modules (Figure S1). However, the demand is more sensitive to the fraction of rooftop capacity, due to our assumption that only rooftop PV installations use the lighter aluminium for their mountings. Decreasing the rooftop fraction to $30 \%$ by 2050 can decrease the cumulative demand from 486 to $450 \mathrm{Mt}$ (Figure S2). However, this reduced demand depends on the continued use of steel for non-rooftop PV, which may not be the case if large fractions of floating and building integrated PV are included in the non-rooftop market segments.

Figure 2 shows that annual demand for aluminium will increase to be as high as $28.5 \mathrm{Mt}$ by 2050 . This annual demand is more than $40 \%$ of the current annual production levels of $65 \mathrm{Mt}$ and more than half of all the aluminium produced by China in 2020 (37 Mt) 27 . Although aluminium is abundant in the world's crust and bauxite reserves are estimated at 30 billion tonnes ${ }^{28}$, aluminium production levels will need to be significantly increased over the next 30 years to meet this demand from PV manufacturing alone. This escalation in demand does not consider the use of aluminium in other clean energy technologies, which is also expected to increase ${ }^{13}$, and its continued use for transport and building infrastructure. Consequently, it can be viewed as a lower limit to actual demand. If the majority of the PV manufacturing continues to be performed in China and supported by local producers, then this demand may need to be met by a mix of local Chinese and imported aluminium production. 


\section{Global Warming Potential of the Required Aluminium Production}

Figure 3 shows the effect of different primary production emissions reduction scenarios on the GWP of the projected aluminium demand. All scenarios assume that $33 \%$ of the projected secondary aluminium pool is available for the PV capacity additions and that the secondary aluminium emissions intensity linearly decreases from the current average value of $0.65 \mathrm{t} \mathrm{CO}_{2} \mathrm{e} / \mathrm{t}$ aluminium (4\% of the emissions of world average primary production in $2020^{17}$ ) to $0.5 \mathrm{t} \mathrm{CO}_{2} \mathrm{e} / \mathrm{t}$ aluminium in 2050 due to efficiency improvements and low $\mathrm{C}$ electricity. In the base scenario (Scenario 1), we assume that the primary production emissions intensity linearly reduces from current levels of $\sim 14.5 \mathrm{t} \mathrm{CO}_{2} \mathrm{e} / \mathrm{t}$ aluminium in $2020^{29,30}$ to the ambitious target of $1.5 \mathrm{t} \mathrm{CO}_{2} \mathrm{e} / \mathrm{t}$ aluminium by 2050 , the latter being the value projected by the IAl as being required to limit temperature increases to $<2{ }^{\circ} \mathrm{C}^{17}$. This reduction in emissions intensity, which can reduce the GWP by $54 \%$ of what would be expected if no reduction in the primary emissions intensity occurs from the current value (Scenario 5 ), is assumed to occur initially primarily via decarbonisation of electricity and then later through process improvements which reduce direct emissions (see Discussion). However, the base scenario still results in a large GWP of $1,672 \mathrm{Mt} \mathrm{CO}_{2}$ e by 2050 . This represents $~ 5 \%$ and $16 \%$ of the global ${ }^{31}$ and Chinese energy-related $\mathrm{CO}_{2}$ emissions in 2019 (Statistica), respectively, and demonstrates the criticality of aluminium resourcing for growth to TW PV.

Table 2

Parameters used in the estimation of the GWP of the calculated aluminium demand.

\begin{tabular}{|c|c|}
\hline Parameter & Value \\
\hline \multicolumn{2}{|l|}{ Aluminium Material Flows } \\
\hline i. Forecast secondary pool (Mt) & Forecast secondary Al pool increasing from $6 \mathrm{Mt}$ in 2020 to $35 \mathrm{Mt}$ in 2050 from Li et al. ${ }^{20}$ \\
\hline $\begin{array}{l}\text { ii. Percentage of secondary pool } \\
\text { used by PV }\end{array}$ & $33.3 \%$ \\
\hline iii. Recycled content (\%) & $34 \%$ in $2020^{19}$ and increasing to $75 \%$ in 2050 \\
\hline iv. Regeneration coefficient & $83 \%$ from Li et al. ${ }^{20}$ (includes collection and recycling efficiency) \\
\hline \multicolumn{2}{|l|}{ Global Warming Potential } \\
\hline $\begin{array}{l}\text { i. Primary production emissions ( } \mathrm{t} \\
\mathrm{CO}_{2} \mathrm{e} / \mathrm{t} \text { aluminium) }\end{array}$ & 14.5 in $2020^{29,30}$ and reducing to the target of 1.5 by 2050 (most ambitious scenario) \\
\hline $\begin{array}{l}\text { ii. Secondary production } \\
\text { emissions ( } \mathrm{t} \mathrm{CO} 2 \mathrm{e} / \mathrm{t} \text { aluminium) }\end{array}$ & $\begin{array}{l}\left.0.65 \text { ( } 4 \% \text { of the emissions of world average primary production }{ }^{17} \text { in } 2020\right) \text { and decreasing to } 0.5 \text { in } \\
2050 \text { due to efficiency improvements and low carbon electricity. }\end{array}$ \\
\hline
\end{tabular}

A number of alternative slower emission intensity reduction scenarios are also shown in Fig. 3 and compared with a more optimistic scenario (Scenario 6) in which the primary production emissions intensity is rapidily reduced to $\sim 5 \mathrm{t} \mathrm{CO}_{2} \mathrm{e} / \mathrm{t}$ aluminium by 2030 by extensive decarbonisation of electricity and then more slowly decreased to the target of $1.5 \mathrm{t} \mathrm{CO} \mathrm{C}_{2} \mathrm{e} / \mathrm{t}$ aluminium by 2050 through process improvements directed at reducing direct emissions. This scenario can decrease the GWP to just $987 \mathrm{Mt} \mathrm{CO}_{2} \mathrm{e}$, which is 28\% of the emissions which could result if no significant change occurs in the primary emissions intensity from its current average value of $14.5 \mathrm{t} \mathrm{CO}_{2} \mathrm{e}$ / $t$ aluminium by 2050. Annual and cumulative emissions are shown for each scenario and their corresponding primary and secondary production contributions are shown in Figure S3. Rapid decarbonisation of electricty will therefore be critical to curtail emissions from minerals production for clean energy technologies such as PV.

Figure 4(a) and (b) show the predicted annual and cumulative emissions from primary and secondary aluminium production when 33\% and $100 \%$, respectively, of China's forecast secondary aluminium pool ${ }^{20}$ is available for added PV capacity. Both projections assume the base primary emissions reduction scenario from Fig. 3. However, the GWP is only reduced by $\sim 7 \%$ if all of China's forecast secondary aluminium is available for the added PV capacity. Since the report by Li et al. ${ }^{20}$, China has increased its volume of imported primary aluminium in an effort to curtail domestic emissions. This additional aluminium, which is not included in the analysis, will increase the secondary pool available for later PV capacity addition, however the additional resource may not be available soon enough to reduce the peak in emissions which is expected to occur in the next 10 years. It will therefore be critical to develop efficient scrap collection and separation systems both for PV and other aluminium uses and to improve secondary aluminium production processes to maximise regeneration efficiency. While aluminium in its purest form can be recycled indefinitely without any degradation or loss of property, the recycling of aluminium alloys can be more complicated $^{32}$. Although most PV module frames use the aluminium 5754 alloy (AlMg3), 6000 series (with Mg and Si) can also be used. Whilst it is straightforward to use EOL frames of both series to remanufacture 6000 series frames, use of 6000 series material to manufacture 5000 series frames is more expensive and requires more complex separation and analysis technology ${ }^{33}$. 
The scenarios presented in Fig. 3 and Fig. 4 assume that the new module capacity added since 2020 operate for 30 years in the field, holding their aluminium as an 'in-product' resource. However, if modules in the field are 'retired' earlier to take advantage of anticipated improvements in module efficiency, they can also release some of this aluminium into the secondary aluminium pool and reduce the amount of primary aluminium production that will be required. However, Fig. 5 shows that retirement of modules after 15 years in the field still does not address the peak that will occur in emissions within the next 10 years and, for the most optimistic primary production emissions scenario, only reduces the GWP by $6 \%$. This suggests the global benefit for China (where the bulk of the aluminium and PV module manufacturing is expected to occur) to increase their aluminium imports now to support a greater fraction of local secondary aluminium production in the future. Another option would be to incentivise use of locally produced aluminium at least for mountings. This could reduce the potential GWP through accessing a larger secondary aluminium pool and possible availability of lower emission primary aluminium, where smelters already have access to low $\mathrm{C}$ hydroelectricity (e.g., in Norway and Russia).

\section{Discussion}

Although, decreasing aluminium usage in PV systems can reduce the expected demand and its associated GWP, this strategy may only be effective if alternative materials used to replace the aluminium do not contribute additional emissions and do not diminish the product's longer-term value in terms of a circular economy. For example, replacing aluminium with steel in PV module frames can reduce PV module resistance to corrosion, make modules heavier and more costly to transport. The predicted demand for aluminium can be reduced by larger increases in module efficiency and module area than anticipated in our model. For example, increasing module area from 1.8 to $3.8 \mathrm{~m}^{2}$ by using larger Si wafers can result in a $16 \%$ reduction in the mass of aluminium required per W. Another route by which aluminium demand of TW PV can be reduced is a more rapid than predicted adoption of frameless modules. Frameless modules are lighter and have a lower embodied energy; however, for the GWP to reduce significantly, this transition would need to occur in the next 10 years.

The most promising route to reduce the GWP of the predicted aluminium demand is to reduce the emissions intensity of primary production. Transforming both aluminium refining and smelting will require significant investment, both for existing aluminium smelters and for new aluminium production capacity which will be required to meet the increased demand. Perhaps the easier task here is the new production capacity which can be sited in Renewable Energy (RE) zones where 100\% renewable power can be used. Currently, the average aluminium emissions intensity using low $\mathrm{C}$ electricity is $5.5 \mathrm{t} \mathrm{CO}_{2} \mathrm{e} / \mathrm{t}$ aluminium (see Table S1). A key advantage of establishing aluminium refineries and smelters within RE zones is that they can absorb excess RE generation and contribute to demand side response ${ }^{23,34}$ by adjusting their operations (e.g., load shedding when energy demand exceeds supply) ${ }^{35}$. However, much of the existing aluminium primary production relies on co-sited thermal coal for the source of power and decoupling of these energy sources is expected to be more complex. Since 2004, China has been the largest primary producer of aluminium producing 37 Mt of aluminium in 2020 ( 60\% of the world's production) ${ }^{27}$. Most of this production uses thermal power from coal. Although electricity decarbonisation may appear an obvious strategy, the scope of this transition needs to be recognised as increased PV production for decarbonised electricity can potentially place further demands on aluminium primary production.

Direct emissions reductions will also be required if emissions intensities are to be reduced to $1.5 \mathrm{t} \mathrm{CO}_{2} \mathrm{e} / \mathrm{t}$ aluminium. Over the past 20 years, large reductions in process-related emissions have been achieved, especially in regard to reducing emissions from perfluorocarbons $(P F C s)^{36}$. In 1990, aluminium sector emissions were $\sim 300 \mathrm{Mt} \mathrm{CO}_{2} \mathrm{e}$, of which direct emissions contributed $200 \mathrm{Mt} \mathrm{CO} 2 \mathrm{e}\left(100 \mathrm{Mt} \mathrm{CO}_{2} \mathrm{e}\right.$ from PFCs). By 2018, the direct emissions share had been reduced from $2 / 3$ to $1 / 3$ of total emissions largely due to reductions in PFC emissions (down to $3 \%$ of the total) and efficiency improvements in the electrolytic smelting process ${ }^{17}$.

New technologies can reduce emissions from the refining of bauxite to alumina, many directed at reducing emissions from the gas which is used to provide the thermal energy ${ }^{34}$. Electric boilers, which produce steam are commercially available for low process heat, however there are limitations to this approach for the higher temperature processes ${ }^{34}$ and, used in the absence of low emissions factor electricity, potential advantages can be eroded ${ }^{23}$. Sources of both power and heat, such as concentrated solar thermal, can provide advantages in regions with rich solar resources ${ }^{37}$. Other options include: (i) biomass co-generation with hydrogen for process heat ${ }^{34}$; and (ii) co-location of aluminium refineries and smelters which can provide savings of up to $22 \mathrm{GJ} / \mathrm{t}$ aluminium by using the heat generated by electrolysis for the calcining step of the Bayer process ${ }^{36}$.

The Hall-Héroult electrolysis process directly generates $\mathrm{CO}_{2}$ at the anode of the electrolytic cell (see Eq. S1). This contributes $0.75 \mathrm{t} \mathrm{CO}_{2} \mathrm{e} / \mathrm{t}$ aluminium via stoichiometry alone, however elimination of these direct emissions remains a challenge. Replacement of currently used pre-

baked $\mathrm{C}$ anodes with an inert anode can avoid these direct emissions by generating $\mathrm{O}_{2}$ instead of $\mathrm{CO}_{2}$ and consequently considerable efforts have been directed at identifying candidate materials for inert electrodes. However, this has been shown to be challenging as inert anodes require high electrical conductivity, resistance to fluoridation, high chemical stability towards oxygen at $1050^{\circ} \mathrm{C}$, high resistance to thermal 
shock, low overvoltage for $\mathrm{O}_{2}$ evolution and preferably can be retrofitted in current electrolysis cell designs ${ }^{38}$. Despite these challenges, a number of early commercialisation activities are occurring ${ }^{34}$. Elysis (a joint venture between Rio Tinto and Alcoa) has commenced construction of commercial-scale inert anode cells in Canada ${ }^{39-41}$, and Rusal (Russia) ${ }^{40}$ and Arctus Metals (Iceland) have reported production of low-C aluminium using insert anode technologies ${ }^{41}$. However, use of inert anodes without decarbonising electricity can increase emissions as the energy consumption of inert anodes is typically $\sim 3 \mathrm{kWh} / \mathrm{kg}$ aluminium higher than existing $\mathrm{C}$ anodes ${ }^{42}$.

\section{Future Perspective}

Due to its 'infinite' recyclability ${ }^{17}$, aluminium can play a critical role in the rapid growth of PV to TW levels by 2050 , a growth that will be required to reduce emissions to net zero. Aluminium's light weight makes it amenable to rooftop PV installations, its resistance to corrosion is highly advantageous for PV modules which are expected to operate in the field for 25 to 30 years and its ability to be extruded as single parts rather than welded can facilitate low-cost PV installations. Although we show that sourcing all the required aluminium for the projected rapid PV growth presents an alarming GWP due to the current insufficiency of secondary aluminium and the high average emissions intensity of primary aluminium production, we suggest that rather than reduce aluminium demand by replacing it with other metals, a more effective approach from the perspective of the circular economy would be to: (i) establish carbon border taxes to provide incentives to reduce the emissions intensity of aluminium primary production and encourage high scrap aluminium collection rates for secondary production; and (ii) introduce landfill taxes to incentivise PV module recycling.

\section{Methods}

\section{Estimation of Aluminium Demand for the Broad Electrification Scenario}

We adopted the ITRPV 2021 technology predictions for trends in module area, module power and percentages of frameless modules; manufacturing data was used for the mass of aluminium used in frames, mountings and inverters. The assumptions used for the aluminium demand calculations are summarised in Table 1 and justified in more detail in Sections S1 and S2 of the Supporting Information. Our base model assumes that PV systems (including inverters) which are installed following 2020 continue to operate in the field for 30 years without replacement and that any additional replacement systems, installed to account for expected performance degradation in the installed systems, is insignificant with respect to the new capacity.

A key assumption in our model was that only rooftop installations use aluminium in their mountings ${ }^{43}$ due to the criticality of light weight for these installations. Even though aluminium can provide superior corrosion resistance compared to steel, typically steel is used in utility scale installations because of its lower cost and greater strength (e.g., for high wind regions). However, depending on the growth of new nonrooftop applications (e.g., floating and building integrated PV) where light weight may be critical, aluminium usage may also be required in non-rooftop installations in the future. As such, our estimated demand should be considered as a lower-case (conservative) scenario.

\section{Potential Global Warming Scenarios}

The GWP of the aluminium demand required for the ITRPV's broad electrification scenario was estimated using a simplified material flow analysis for a number of different scenarios assumed to occur in China. China was selected as it is currently, and expected to continue to be, the dominant manufacturer of crystalline silicon modules ${ }^{44}$. It was also the largest primary producer of aluminium in $2020^{45}$. Our analysis assumed that the aluminium required for PV module production was produced through a combination of primary and secondary production, with forecast annual secondary aluminium production levels predicted by Li et al. for China ${ }^{20}$. These forecast values were based on known resources of in-product aluminium and predicted aluminium use, an average service lifetime for aluminium parts of 16 years and a regeneration coefficient of $83 \%$ (which includes collection of scrap Al). Given that it is unrealistic to expect that all the available secondary aluminium is directed into PV manufacturing, the sensitivity of the GWP of the aluminium demand to the fraction of this pool used was evaluated for the case of $33 \%$ and $100 \%$ of scrap aluminium pool usage. The percentage of recycled content in the aluminium used for the added capacity was assumed to linearly increase from $34 \%$ in $2020^{19}$ to $75 \%$ in 2050 and all other parameters are as listed in Table 2 .

We assumed a primary production emissions intensity of $14.5 \mathrm{t} \mathrm{CO}_{2} \mathrm{e} / \mathrm{t}$ aluminium ${ }^{29,30}$ for 2020 and then considered different primary production emissions reduction scenarios to determine how they affected the GWP of the estimated aluminium demand. These scenarios included linear reductions in the primary production emissions intensity to 2050 targets of 1.5 (base scenario), $3.5,5.5$ and $7.5 \mathrm{t} \mathrm{CO} \mathrm{e}_{2} / \mathrm{t}$ aluminium and compared the resulting GWP with the worst case scenario where the emissions intensity is unchanged at $14.5 \mathrm{t} \mathrm{CO}_{2} \mathrm{e} / \mathrm{t}$

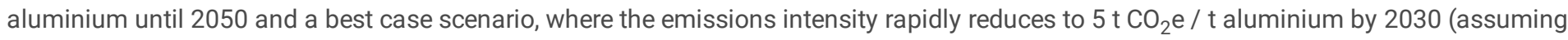
rapid decarbonisation of electricity) and then more gradually reduces to the target of $1.5 \mathrm{t} \mathrm{CO}_{2} \mathrm{e} / \mathrm{t}$ aluminium by 2050 via process 
improvements. The secondary production emissions intensity was assumed to reduce to a lesser extent from a value that is $\sim 4 \%$ of world average primary production emissions ${ }^{17}\left(0.65 \mathrm{t} \mathrm{CO}_{2} \mathrm{e} / \mathrm{t}\right.$ Al) to $0.5 \mathrm{t} \mathrm{CO2e} \mathrm{/} \mathrm{t} \mathrm{aluminium} \mathrm{by} 2050$ (i.e., $0.5 \%$ reduction per year) due to process improvements.

\section{Declarations}

\section{Author Contributions}

Alison Lennon conceived of the publication concept, conducted the modelling and was the primary author of the manuscript. Marina Lunardi and Pablo R Dias contributed to the discussion of sustainability and recycling and Brett Hallam to the discussion on projected PV technology trends. All authors contributed to the manuscript structure and proof reading.

\section{Acknowledgements}

This work has been supported by the Australian Research Council (ARC) through the Future Fellowship FT170100447 (awarded to Alison Lennon) and the Australian Renewable Energy Agency (ARENA) research grant 2017/RND002. The authors also acknowledge funding support from the Australian Centre of Advanced Photovoltaics (ACAP), which is also funded by ARENA. Prof. Jenny Buchan (UNSW, Sydney, Australia) and Dr Chris Preston (University of Sydney, Sydney, Australia) are thanked for proof reading of the manuscript.

\section{References}

1. Peters, G. P. et al. The challenge to keep global warming below $2^{\circ} \mathrm{C}$. Nature Climate Change $3,4-6,10.1038 / \mathrm{nclimate} 1783$ (2013).

2. IEA. Renewables 2020: Analysis and forecast to 2025, https://www.iea.org/reports/renewables-2020/solar-pv (2020).

3. IEA. Net Zero by 2050: A Roadmap for the Global Energy Sector, https://www.iea.org/reports/net-zero-by-2050 (2021).

4. ITRPV. International Technology Roadmap for Photovoltaics (ITRPV.net): Results 2020, 1-20, http://www.itrpv.net/Reports-/-Downloads/ (2021).

5. IRENA. Electricity storage and renewables: Costs and markets to 2030, http://www.irena.org (2017).

6. IRENA. Future of Solar Photovoltaic: Deployment, investment, technology, grid integration and socio-economic aspects, https://irena.org/-/media/Files/IRENA/Agency/Publication/2019/Nov/IRENA_Future_of_Solar_PV_2019.pdf (2019).

7. IEA. Energy Technology Perspectives 2017, https://www.iea.org/reports/energy-technology-perspectives-2017 (2017).

8. Creutzig, F. et al. The underestimated potential of solar energy to mitigate climate change. Nat. Energy 2, 17140, 10.1038/nenergy.2017.140 (2017).

9. Victoria, M. et al. Solar photovoltaics is ready to power a sustainable future. Joule 5, 1041-1056, https://doi.org/10.1016/j.joule.2021.03.005 (2021).

10. Verlinden, P. J. Future challenges for photovoltaic manufacturing at the terawatt level. Journal of Renewable and Sustainable Energy 12 , 053505, http://10.1063/5.0020380 (2020).

11. IEA. Projected Costs of Generating Electricity, https://www.iea.org/reports/projected-costs-of-generating-electricity-2020 (2020).

12. IRENA. Renewable Capacity Statistics 2021, https://www.irena.org/publications/2021/March/Renewable-Capacity-Statistics-2021 (2021).

13. Hund, K., La Porta, D., Fabregas, T. P., Laing, T. \& Drexhage, J. Minerals for Climate Action: The Mineral Intensity of the Clean Energy Transition, https://pubdocs.worldbank.org/en/961711588875536384/Minerals-for-Climate-Action-The-Mineral-Intensity-of-the-CleanEnergy-Transition.pdf (Washington, DC, 2020).

14. IEA. The Role of Critical Minerals in Clean Energy Transitions, https://www.iea.org/reports/the-role-of-critical-minerals-in-clean-energytransitions (2021).

15. Gervais, E., Shammugam, S., Friedrich, L. \& Schlegl, T. Raw material needs for the large-scale deployment of photovoltaics - Effects of innovation-driven roadmaps on material constraints until 2050. Renewable and Sustainable Energy Reviews 137, 110589, https://doi.org/10.1016/j.rser.2020.110589 (2021).

16. Bödeker, J. M., Bauer, M. \& Pehnt, M. Aluminium and Renewable Energy Systems - Prospects for the Sustainable Generation of Electricity and Heat https://www.world-aluminium.org/media/filer_public/2013/01/15/fl0000407.pdf (2010).

17. IAI. Aluminium Sector Greenhouse Gas Pathways to 2050, https://www.worldaluminium.org/media/filer_public/2021/03/16/iai_ghg_pathways_position_paper.pdf (2021).

Page 8/13 
18. Tsakiridis, P. E. Aluminium salt slag characterization and utilization - A review. Journal of Hazardous Materials 217-218, 1-10, https://doi.org/10.1016/j.jhazmat.2012.03.052 (2012).

19. Zhu, Y. \& Cooper, D. R. An Optimal Reverse Material Supply Chain for U.S. Aluminum Scrap. Procedia CIRP 80, 677-682, https://doi.org/10.1016/j.procir.2019.01.065 (2019).

20. Li, Y., Yue, Q., He, J., Zhao, F. \& Wang, H. When will the arrival of China's secondary aluminum era? Resources Policy 65, 101573, https://doi.org/10.1016/j.resourpol.2019.101573 (2020).

21. Kvande, H. The Aluminum Smelting Process. Journal of Occupational and Environmental Medicine 56 (2014).

22. Bertram, M., Martchek, K. J. \& Rombach, G. Material Flow Analysis in the Aluminum Industry. 13, 650-654, https://doi.org/10.1111/j.1530-9290.2009.00158.x (2009).

23. Brough, D. \& Jouhara, H. The aluminium industry: A review on state-of-the-art technologies, environmental impacts and possibilities for waste heat recovery. International Journal of Thermofluids 1-2, 100007, https://doi.org/10.1016/j.ijft.2019.100007 (2020).

24. Bayer, K. J. Process of Obtaining Alumina. US patent 382,505 (1888).

25. Haupin, W. E. Electrochemistry of the Hall-Heroult process for aluminum smelting. Journal of Chemical Education 60,279 , 10.1021/ed060p279 (1983).

26. Jordan, D. C., Kurtz, S. R., VanSant, K. \& Newmiller, J. Compendium of photovoltaic degradation rates. Prog. Photovolt: Res. Appl. 24, 978-989, 10.1002/pip.2744 (2016).

27. IAl. International Aluminium Organisation: Statistics, https://international-aluminium.org/ (2021).

28. USGS. Mineral Commodity Summaries 2020, https://pubs.usgs.gov/periodicals/mcs2020/mcs2020.pdf (2020).

29. Hao, H., Geng, Y. \& Hang, W. GHG emissions from primary aluminum production in China: Regional disparity and policy implications. Appl. Energy 166, 264-272, https://doi.org/10.1016/j.apenergy.2015.05.056 (2016).

30. Ding, N., Liu, N., Lu, B. \& Yang, J. Life cycle greenhouse gas emissions of aluminum based on regional industrial transfer in China. Journal of Industrial Ecology Online, https://doi.org/10.1111/jiec.13146 (2021).

31. IEA. Global Energy Review: CO2 Emissions in 2020, https://www.iea.org/articles/global-energy-review-co2-emissions-in-2020 (2021).

32. van Schaik, A. \& Reuter, M. A. Chapter 22 - Material-Centric (Aluminum and Copper) and Product-Centric (Cars, WEEE, TV, Lamps, Batteries, Catalysts) Recycling and DfR Rules in Handbook of Recycling (eds Ernst Worrell \& Markus A. Reuter) pp. $307-378$ (Elsevier, 2014).

33. Bauer, A. J. R. \& Laska, C. LIBS for Automated Aluminium Scrap Sorting, https://tsi.com/getmedia/b79aa0dd-35de-4bd5-9b6aaa4ea7cd096f/LIBS_Automated_Aluminum_Scrap_Sorting_LIBS-028-A4?ext=.pdf (2018).

34. Butler, C., Maxwell, R., Graham, P. \& Hayward, J. Australian Industry Energy Transitions Initiative Phase 1 Technical Report, Report No. 978-0-9871341-9-6, (2021).

35. Goulden, M., Spence, A., Wardman, J. \& Leygue, C. Differentiating 'the user' in DSR: Developing demand side response in advanced economies. Energy Policy 122, 176-185, https://doi.org/10.1016/j.enpol.2018.07.013 (2018).

36. Moya, J. A. et al. Energy Efficiency and GHG Emissions: Prospective Scenarios for the Aluminium Industry, https://publications.jrc.ec.europa.eu/repository/bitstream/JRC96680/Idna27335enn.pdf (2015).

37. Kraemer, S. Australian Researchers Assess the Commercial Viability of Solar Alumina Calcining, https://www.solarpaces.org/australianresearchers-assess-the-commercial-viability-of-solar-alumina-calcining/ (2020).

38. Padamata, S. K., Yasinskiy, A. S. \& Polyakov, P. V. Progress of inert anodes in aluminium industry: Review. Journal of Siberian Federal University. Chemistry 2018 11, 18-30 (2018).

39. IEA. Aluminium, https://www.iea.org/reports/aluminium (Paris, 2020).

40. Yasinskiy, A. S., Padamata, S. K., Polyakov, P. V. \& Shabanov, A. V. An update on inert anodes for aluminium electrolysis. Light Metals, Carbon Materials 1, 15-23, http://10.17580/nfm.2020.01.03 (2020).

41. Haller, M. Y., Carbonell, D., Dudita, M., Zenhäusern, D. \& Häberle, A. Seasonal energy storage in aluminium for 100 percent solar heat and electricity supply. Energy Conversion and Management 5, 100017, https://doi.org/10.1016/j.ecmx.2019.100017 (2020).

42. Solheim, A. Inert Anodes-the Blind Alley to Environmental Friendliness? in Light Metals 2018. TMS 2018. The Minerals, Metals \& Materials Series Light Metals 2018 (ed O. Martin) pp. 1253-1260 (Springer International Publishing, 2018).

43. IEA. Life Cycle Inventories and Life Cycle Assessments of Photovoltaic Systems 2020, (2020).

44. BloombergNEF. Solar PV Trade and Manufacturing: A Deep Dive, https://www.csis.org/analysis/industrial-policy-trade-and-clean-energysupply-chains (2021). 
45. IEA. Technology Roadmap: Solar Photovoltaic Energy,

https://www.iea.org/media/freepublications/technologyroadmaps/solar/TechnologyRoadmapSolarPhotovoltaicEnergy_2014edition.pdf (International Energy Agency, 2014).

46. Philipps, S. Photovoltaics Report, https://www.ise.fraunhofer.de/content/dam/ise/de/documents/publications/studies/Photovoltaics-

Report.pdf (Fraunhoher Institute for Solar Energy Systems, Freiberg, Germany, 2020).

47. Stamford, L. \& Azapagic, A. Environmental Impacts of Photovoltaics: The Effects of Technological Improvements and Transfer of Manufacturing from Europe to China. Energy Technology 6, 1148-1160, https://doi.org/10.1002/ente.201800037 (2018).

Figures

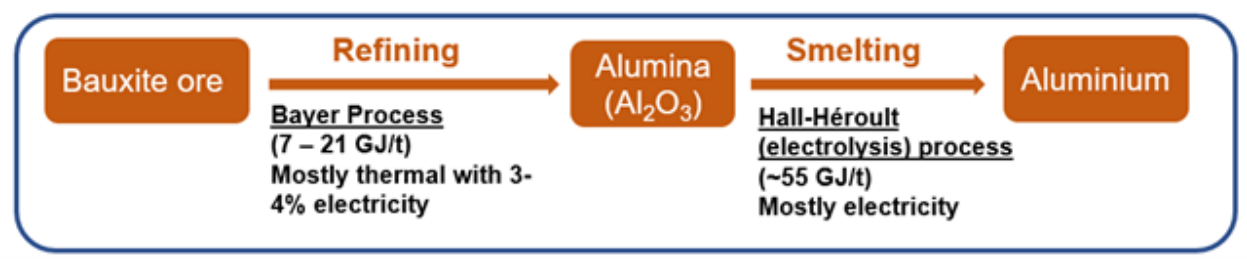

Figure 1

Flowchart of the aluminium primary production process showing energy requirements. The refining and smelting processes are described in more detail in Section S2 of the Supporting Information.

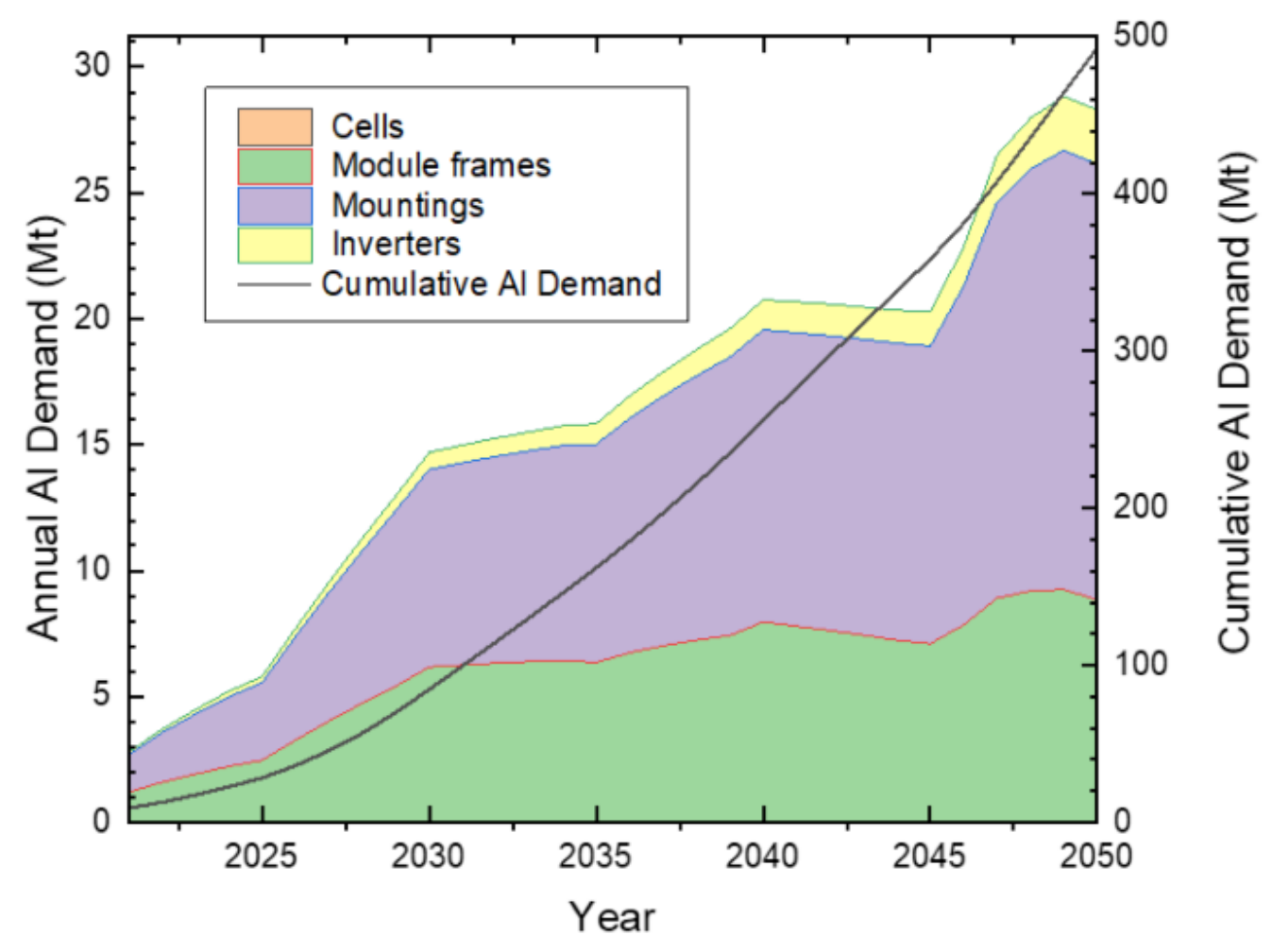

Figure 2

Annual (left) and cumulative (right) aluminium demand for the ITRPV's broad electrification scenario from 2021-2050 for the base case of the share of rooftop PV installations decreasing from $50 \%$ to $40 \%$ by 2050 . The estimated demand assumed that additional demand due to module degradation in the field was insignificant compared with the annual capacity additions predicted by the roadmap. 


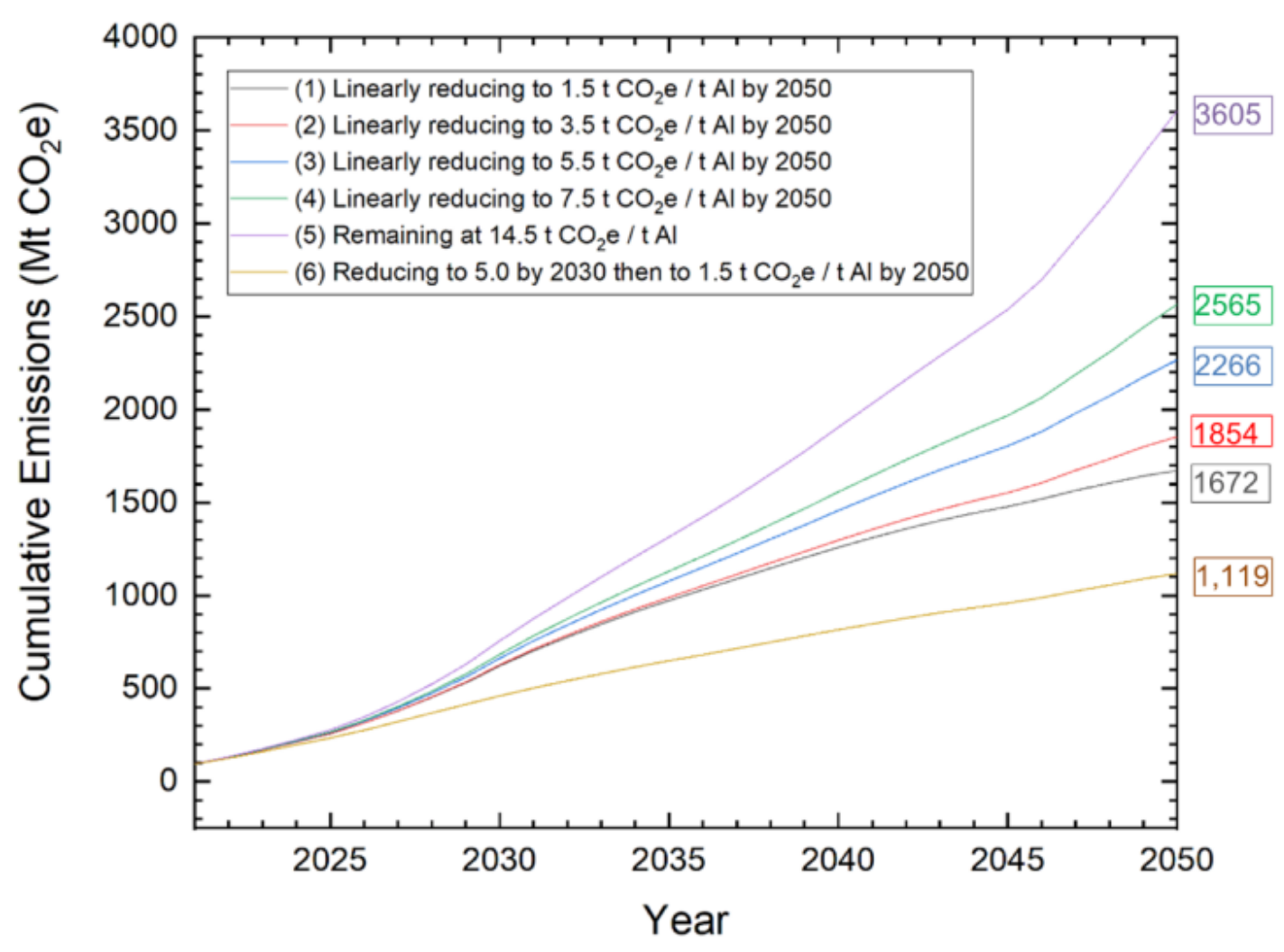

Figure 3

Global warming potential (in Mt $\mathrm{CO} 2 \mathrm{e}$ ) of the estimated aluminium demand from Figure 2 for different primary emissions reduction scenarios. All scenarios assumed that $33 \%$ of the forecast secondary aluminium pool for China (from Li et al. 20) is available for the production of the new PV modules. All other parameters used for the modelling are as listed in Table 2. 
(a)

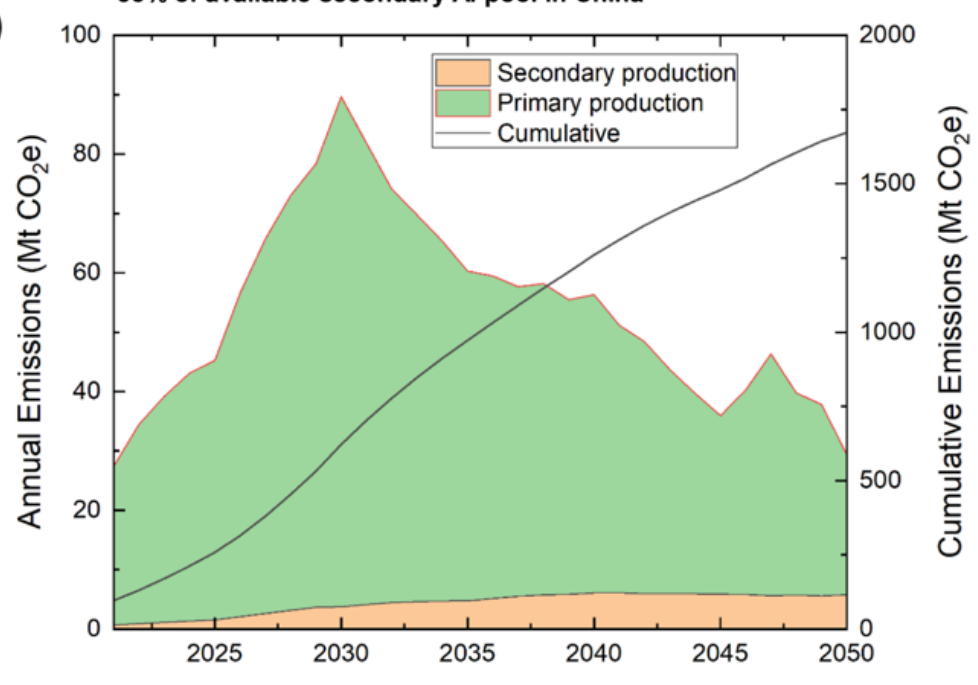

(b)

b) $100 \%$ of available secondary Al pool in China

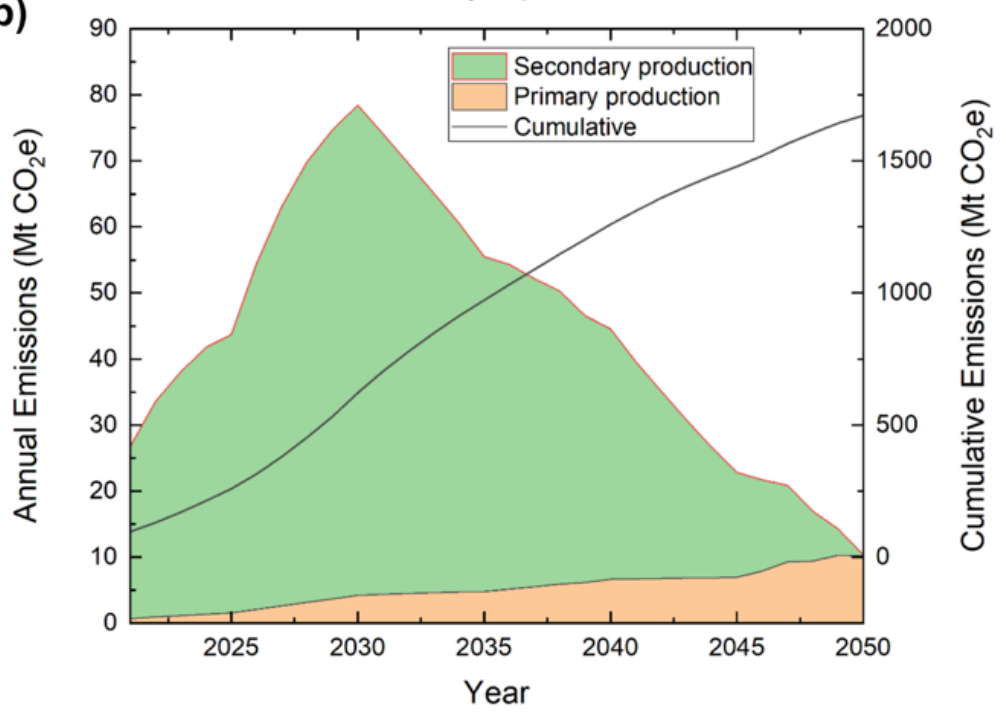

\section{Figure 4}

Annual (left) and cumulative (right) emissions from primary and secondary aluminium production in China required for the aluminium demand shown in Figure 2 with (a) and (b) assuming 33\% and 100\%, respectively, of the forecast available pool of secondary aluminium in China 20 is available for new PV module production in China. All other parameters used for the modelling are as listed in Table 2. 

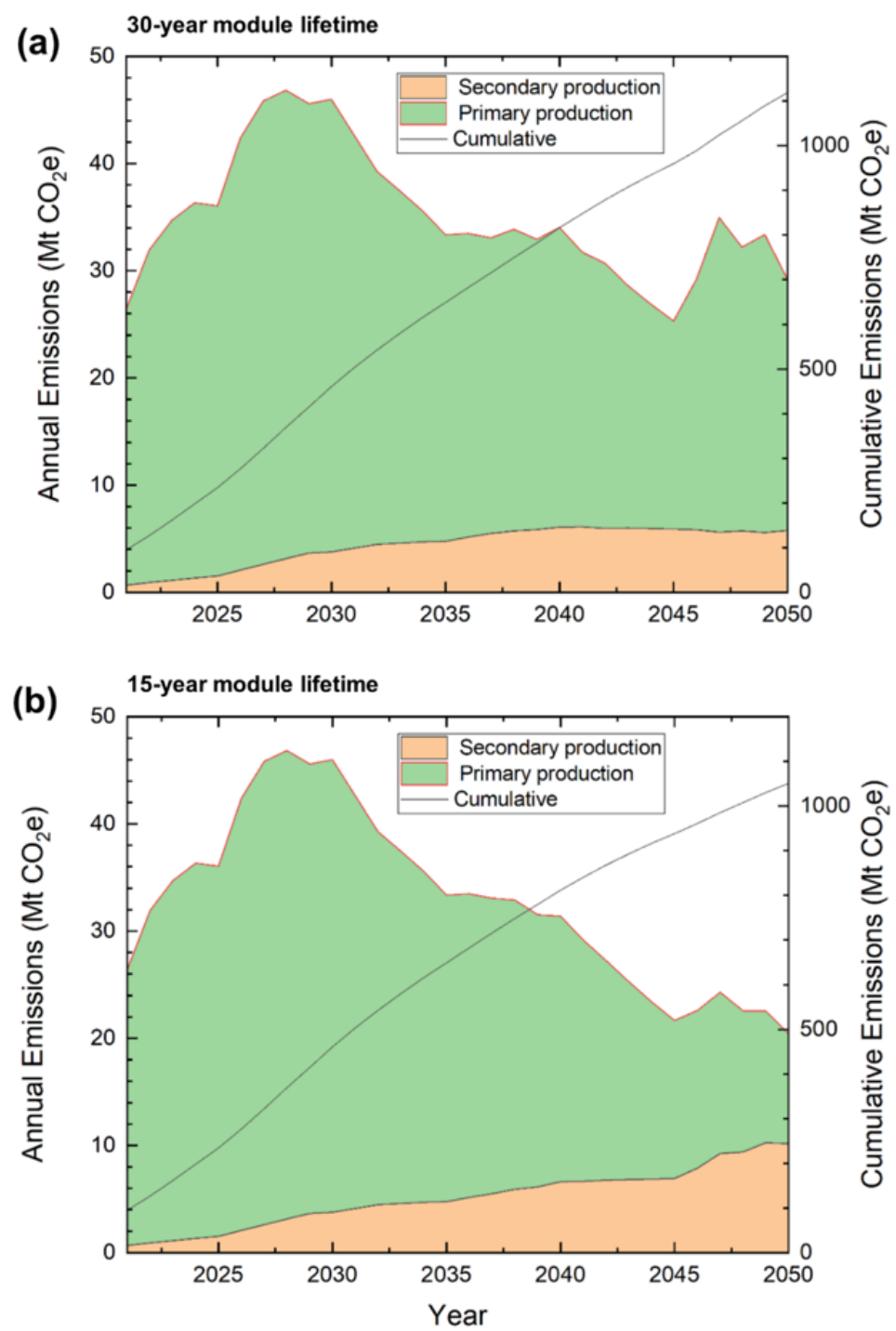

\section{Figure 5}

Annual (left) and cumulative (right) emissions of the estimated aluminium demand from Figure 2 from primary and secondary aluminium production assuming a module lifetime in the field of (a) 30 years; and (b) 15 years. The projections assume that the primary production emissions intensity reduces linearly from 14.5 to $5 \mathrm{t} \mathrm{CO2e} \mathrm{/} \mathrm{t}$ aluminium by 2030 and then more slowly to $1.5 \mathrm{t} \mathrm{CO2e} \mathrm{/} \mathrm{t}$ aluminium by 2050 (i.e., Scenario 6 in Figure 4). All other factors as listed in Table 2.

\section{Supplementary Files}

This is a list of supplementary files associated with this preprint. Click to download.

- AluminiumDemandRiskfromPVSupportingInformationSubmitted.pdf 